\title{
Estimation of ungauged Bahr el Jebel flows based on upstream water levels and large scale spatial rainfall data
}

\author{
G. Petersen ${ }^{1}$, H. Bast ${ }^{1}$, and N. Fohrer ${ }^{2}$ \\ ${ }^{1}$ HR Wallingford Ltd, Howbery Park, Wallingford, Oxfordshire, OX10 8BA, UK \\ ${ }^{2}$ Christian-Albrechts-University of Kiel, Ecology Centre, Department of Hydrology and Water Resources Management, \\ Olshausenstr. 75, 24118 Kiel, Germany
}

Received: 16 January 2008 - Revised: 1 March 2008 - Accepted: 28 May 2008 - Published: 20 June 2008

\begin{abstract}
The study derives Bahr el Jebel flow data at Mongalla, combining upstream flow from Lake Albert and torrential runoff derived from the Collaborative Historical African Rainfall Model (CHARM) rainfall data in the catchment between Lake Albert and Mongalla using GIS techniques. The results provide an updated rating curve for Lake Albert outflows and currently unavailable flow data at Mongalla, the entry to the Sudd swamp, with a high level of confidence for the period after 1983; data which are essential for detailed hydrological assessments of the swamp system with its significant importance for the economies and lives of people in the area.
\end{abstract}

\section{Introduction}

Mongalla, a town situated at the upper reach of the White Nile, here called the Bahr el Jebel, is the key gauging station for inflows into the Sudd swamps of southern Sudan, one of the world largest wetlands. Due to political instability, flow measurements have been suspended in 1983, leaving the inflow into the swamps ungauged. The flows at Mongalla are a combination of Lake Victoria discharge, influenced by evaporation, damping and storage effects of the Equatorial Lakes (Albert, Edward, Kyoga) and seasonal torrent runoff during the rainy season. The study area is shown in Fig. 1.

Historically, the importance of the torrent flows for processes in the Sudd swamps, like their influence on the flood extent and yearly variations, was reported by Hurst and Phillips (1938). They described the Equatorial Lakes discharges as not varying significantly over the seasons in normal years and having a fair correlation between flows of suc-

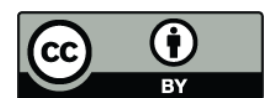

Correspondence to: G. Petersen (g.petersen@hrwallingford.co.uk) cessive years. The torrents on the other hand are highly seasonal and depend on the local rainfall pattern, with the flow in successive years depending solely on the rainfall and not showing any serial relation despite to the general rainfall pattern which fluctuates over the years.

JIT (1954) describe the flow reaching Mongalla, the gateway of the Sudd swamps, as being made up of two components, the discharge of the Equatorial Lakes and the torrential runoff from the upstream hilly areas. To capture the influence of the torrents, the area upstream of the Sudd swamps, namely the hilly area between Juba and Nimule as well as further upstream to Lake Albert, had to be considered. JIT (1954) showed that for average years the contribution from the Equatorial Lakes varies only from 1700 to $2000 \times 10^{6} \mathrm{~m}^{3} /$ month. On the other hand, over the period from 1915 to 1919 the total flow at Mongalla averaged $3300 \times 10^{6} \mathrm{~m}^{3} /$ month, while the torrents reached a monthly mean discharge of over $3000 \times 10^{6} \mathrm{~m}^{3} /$ month in September 1916 and over $4500 \times 10^{6} \mathrm{~m}^{3} /$ month in September 1917; values considerably higher than the corresponding lake discharges of 2000 and $2600 \times 10^{6} \mathrm{~m}^{3} /$ month respectively. In 1918 however the torrents never exceeded a monthly average of $400 \times 10^{6} \mathrm{~m}^{3} /$ month.

This general picture highlights the importance of the torrential flows for the total discharges at Mongalla, which in turn would be important for any hydrologic analysis of the Sudd swamps. As Mongalla is a key gauge for understanding the processes in the Sudd, estimating the missing records is beneficial for any study in this area. The objective of this paper therefore is to estimate the important missing flow data at Mongalla from the two components of Lake Albert flow and torrent runoff. As the torrent flows are not gauged, they are deduced from spatial rainfall fields using the overlapping time periods where both Lake Albert outflows and Mongalla flows are available for calibration of the torrent flows. Lake Albert flows have been generated from lake levels measured

Published by Copernicus Publications on behalf of the European Geosciences Union. 


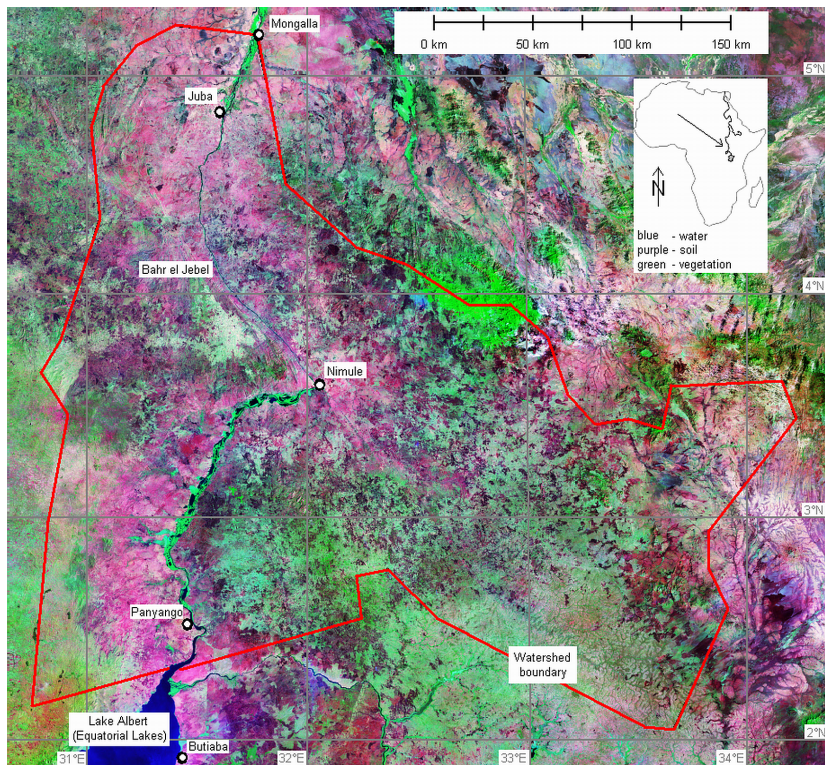

Fig. 1. Area overview prepared from Landsat satellite imagery showing Lake Albert, the torrent catchment area and Mongalla gauging station. The Sudd swamps are located north of Mongalla, Lake Victoria is south of Lake Albert.

at Butiaba utilizing newly generated rating curves. The paper describes how this work was carried out and evaluates the generated data for their suitability as base data for further hydrological assessments.

\section{Methods}

\subsection{Study area description}

The study area stretches for $438 \mathrm{~km}$ along the Bahr el Jebel from the exit of Lake Albert in Uganda to Mongalla in Sudan. The landscape is dominated by the river valley with the land rising into hilly terrain to the east and west. Rainfall in this area is highly seasonal and occurs in the rainy season between April and November yielding $943 \mathrm{~mm}$ annually. Vegetation cover, consisting of grass and acacia bushland, is varying with the season. Runoff discharges into the Bahr el Jebel through seasonal riverbeds. The catchment area between the exit of Lake Albert and Mongalla gauge which provides torrential runoff was determined using the USGS Geospatial Streamflow Model (Entenman, 2006). The $74000 \mathrm{~km}^{2}$ catchment area is shown in Fig. 1; its typical features are shown in Fig. 2.

\subsection{Approach to the problem and flow data sources}

Data for locations within the area of interest are available for different periods of time as shown in Table 1. These datasets provide sufficient overlapping information to estimate missing periods of data based on correlation factors.

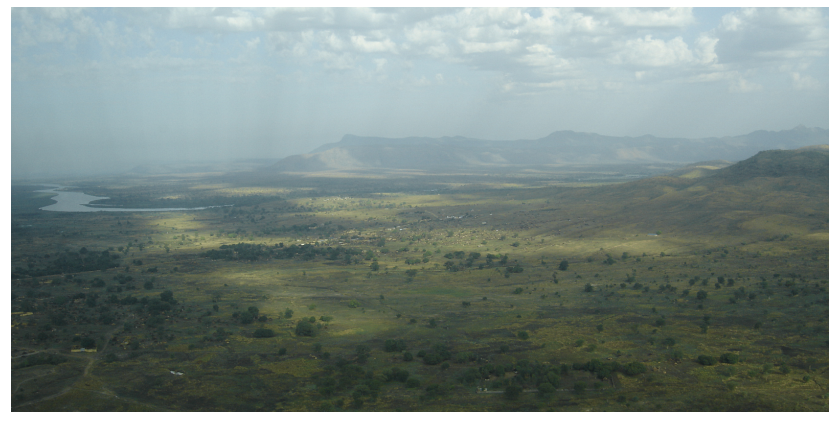

Fig. 2. Catchment area at Nimule. Looking west, Nimule is in the centre of the image and the distinctive right angle Nile bend is visible on the left.

Two overlapping periods were used for establishing these correlations. Panyango flows were used to calibrate calculated Lake Albert discharges, and combined Mongalla flow and rainfall runoff datasets for the period from 1961 to 1983 were used to calibrate and validate correlation coefficients for Mongalla (Hurst and Phillips, 1933), from which new flow data at Mongalla were estimated for the period from 1984 to 1996. Further estimating would be possible with additional rainfall datasets using the same principles.

Torrent flows were historically not directly measured but can be estimated by the difference between Lake Albert outflows and flows measured at Mongalla (Hurst and Phillips, 1938) using a principle as shown in Fig. 3. As there is no permanent gauging station at the outlet of Lake Albert, outflows have to be deduced from a rating curve based on lake water levels measured at Butiaba and flows measured at Mongalla during the dry season (1). Losses through evapotranspiration and gains through dry season catchment runoff have to be taken into account with an estimated value of 5\% of the Mongalla flows (Hurst and Phillips, 1938). The calculated Lake Albert outflow datasets (2) were validated with flow records measured at Panyango (3).

The rating curve for the Lake Albert discharges is altered by vegetation dynamics which in return are influenced by high or low flow conditions (Petersen et al., 2007). The curve was deduced by plotting monthly average Butiaba gauge readings against discharges at Mongalla for the dry season, split up into different periods of years which were selected according to significant flow conditions. The flows were validated with data measured at Panyango near the outlet of Lake Albert. For the White Nile at Mongalla, they provide dry season flows and base flows during the rainy season.

\subsection{Rainfall time series and torrent flows based on CHARM data}

The rainfall data used in the analysis are based on CHARM data, a grid-based rainfall dataset called the Collaborative Historical African Rainfall Model which spans the time 
Table 1. Availability of data for different locations.

\begin{tabular}{lll}
\hline \multicolumn{1}{c}{ Year } & & \\
\hline Lake Albert water levels & $1904-2004$ & 190019101920193019401950196019701980199020002010 \\
Flow at Mongalla & $1905-1983$ & $1961-1996$ \\
CHARM spatial rainfall & $1969-1979$ & $1996-2004$
\end{tabular}

period 1961 to 1996 in daily resolution. The two key sources of data for CHARM are the National Centre for Environmental Prediction (NCEP) reanalysis time-series and station data. The daily estimated precipitation fields from the reanalysis are smoothed with a spatial filter (Funk et al., 2003). This generates a set of "synoptic" rainfall fields at a cell size resolution of 0.1 degree, equal to $11.2 \mathrm{~km}$ in the area of interest.

Based on the methodology shown in Fig. 3, the rainfall data have been extracted from the CHARM grids for the catchment area between Lake Albert and Mongalla (4) for the period from 1961 to 1996 . For the extraction of time series data from the daily spatial CHARM layers (5) a GIS tool was developed within the ESRI ArcGIS 9.2 (ESRI, 2007) environment using ArcObjects. The tool was built for a cell by cell extraction of daily rainfall values within a period of 36 consecutive years. The area of interest consists of 1224 single cells, which results in 421575 values for one year and 15186700 values for the whole dataset (with some values missing). The tool extracts the values of all overlaying layers at a specific location for a specified cell. The data were analyzed calculating average, minimum and maximum values as well as the spatial distribution and extent of rainfall events resulting in an averaged rainfall time series for the area of interest (6). The values were then converted to runoff flow quantities (7) considering a runoff function to capture initial infiltration and losses which was derived through calibration with overlapping flow datasets using Eq. 1. The power of 3 in combination with the reduction factor $\mathrm{F}_{\text {red }}$ simulates the nonlinear behaviour of runoff caused by rainfall of different intensities including different relative infiltration rates and the degree of soil pre-saturation. For the calibration, the torrent flow was assumed to be the difference between flow at Mongalla and flow at Lake Albert outlet, i.e. Panyango less the estimated losses as described in Sect. 2.2.

$\mathrm{Q}_{\text {torr }}=\mathrm{Q}_{\text {rain }}^{3} \times \mathrm{F}_{\text {red }}$

with

$\mathrm{Q}_{\text {torr }}=$ Torrent runoff quantity in the whole catchment $\left(\mathrm{m}^{3} /\right.$ month)

$\mathrm{Q}_{\text {rain }}=$ Rainfall quantity in the whole catchment ( $\left.\mathrm{m}^{3} / \mathrm{month}\right)$ $F_{\text {red }}=$ Reduction factor accounting for initial infiltration and losses

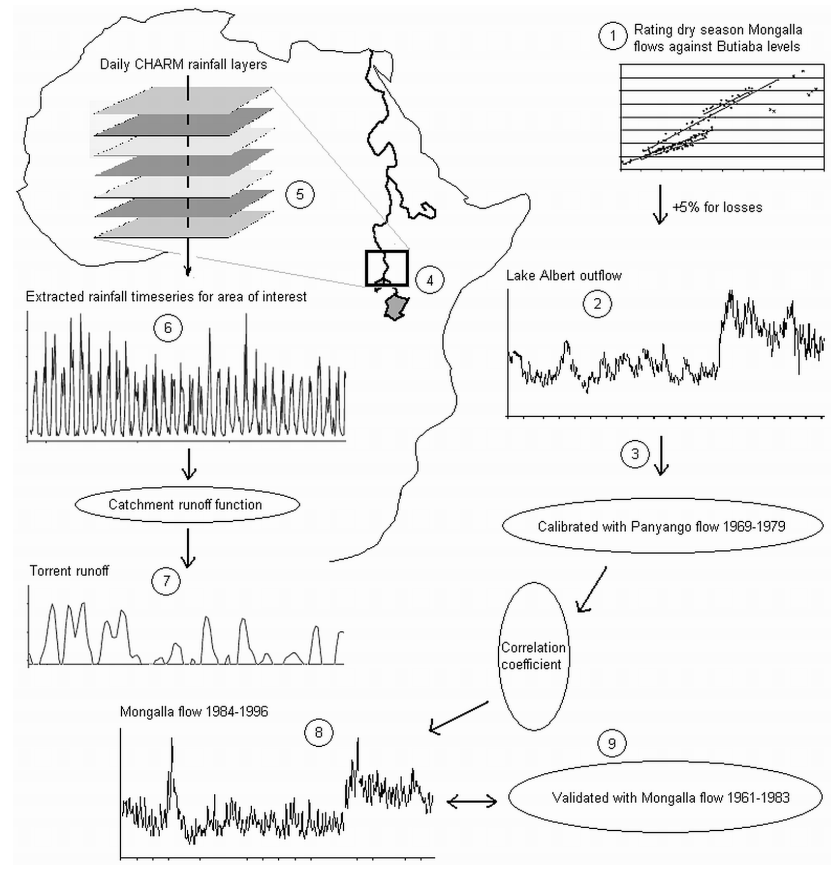

Fig. 3. Principles of data processing and interactions utilizing timeseries (1-3) and spatial rainfall data (4-7) which are then combined (8-9) to calculate Mongalla flows.

\subsection{Estimating Mongalla flows}

Adding Lake Albert discharges and the torrent runoff, the discharges at Mongalla were calculated (8). For calibration of the flows, overlapping pre 1983 datasets were used and a correlation factor applied to cater for damping effects. Assuming that the Lake Albert flows were sufficiently accurate, the flow data was calibrated in order to match the Mongalla flows when combined with the Lake Albert discharge for the overlapping period from 1961 to 1983 (9). The level of confidence in the estimated Mongalla flow data was established taking into account points of potential uncertainty including uncertainties in Lake Albert outflow, the CHARM data and the assumptions made in calculating the runoff using sensitivity calculations. Sensitivity trials have been conducted to gauge the effect of the different parameters in the overlapping period. The method was then applied to the post 1983 


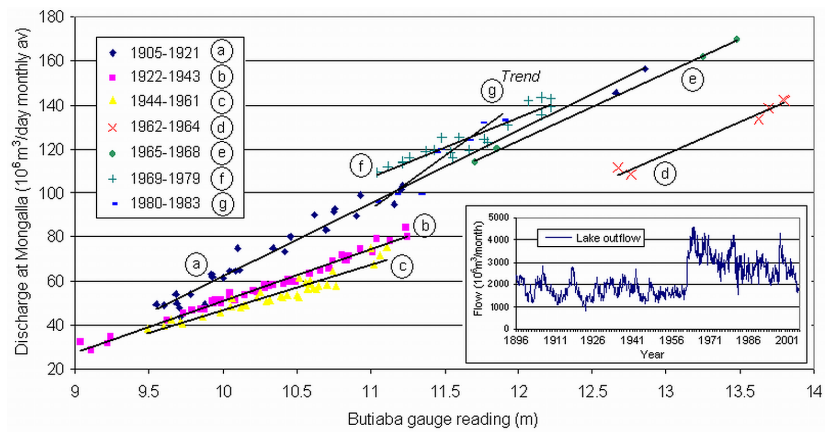

Fig. 4. Dry season rating curves for Lake Albert outflow for periods with different typical flow conditions based on Lake Victoria outflow.

data to generate the Mongalla flow to 1996. For periods of missing Lake Albert records, outflow was estimated using linear interpolation, crosschecking qualitatively with outflow data from upstream Lake Victoria.

\section{Results}

\subsection{Lake Albert outflow}

Lake Albert outflows are based on a rating curve converting lake water levels at Butiaba into flows at Mongalla. These are assumed to be similar to those at Panyango (see Sect. 2.3). As the flows leaving the lake are sensitive to changing vegetation conditions which depend on high or low flows (Petersen et al., 2007), different rating curves have been established for the changing flow regimes in different years as shown in Fig. 4.

The curves represent:

1. 1905-1921 showing historical flow conditions

2. 1922-1943 less flow leaves the lake as vegetation may have choked the exit of the lake during low flows in 1922

3. 1944-1961 continuous low flow conditions and possibly vegetation growth lead to further decrease of outflow

4. 1962-1964 very high flow events during this period lead to increased outflow

5. 1965-1968 the rating curve has changed significantly due to opened up channels

6. 1969-1979 comparatively higher discharges occur during this period

7. 1980-1983 flows reduce, assumingly due to decreasing channel capacity with low flows allowing vegetation growth. The change in direction describes this trend

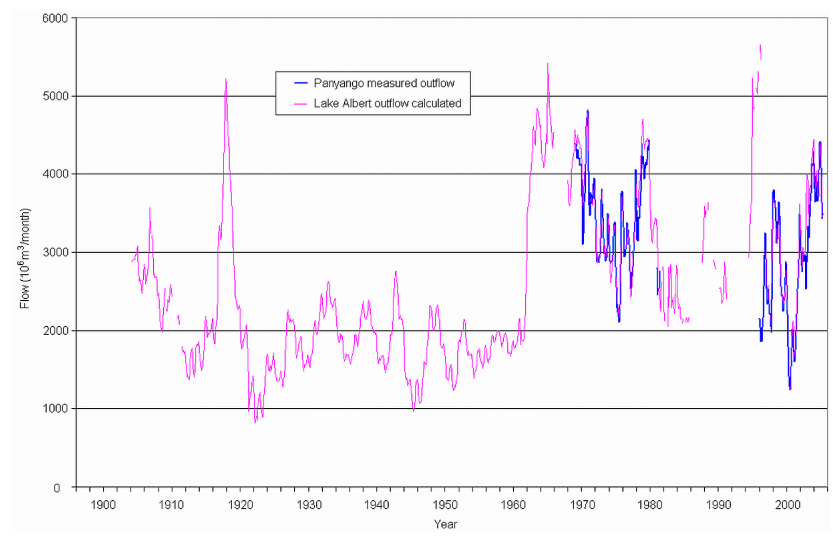

Fig. 5. Comparison of calculated and measured Lake Albert outflow based on the relevant rating curve and calibrated using a correction coefficient, gaps are caused by missing input data.

Table 2. Regression functions for dry season Lake Albert outflow for different periods as shown in Fig. 4.

\begin{tabular}{llll}
\hline Curve & Period & Regression function & \\
\hline a & $1905-1921$ & $y=33.058 x-268.31$ & $(2)$ \\
a & $1922-1943$ & $y=23.363 \mathrm{x}-182.66$ & $(3)$ \\
$\mathrm{c}$ & $1944-1961$ & $y=20.732 \mathrm{x}-160.75$ & $(4)$ \\
$\mathrm{d}$ & $1962-1964$ & $y=28.980 \mathrm{x}-258.68$ & $(5)$ \\
$\mathrm{e}$ & $1965-1968$ & $y=38.465 \mathrm{x}-336.45$ & $(6)$ \\
$\mathrm{f}$ & $1969-1979$ & $y=53.696 \mathrm{x}-515.202$ (calibrated) & $(7)$ \\
$\mathrm{g}$ & $1980-1983$ & $y=68.519 \mathrm{x}-691.114$ (calibrated) & $(8)$ \\
$\mathrm{h}$ & $1984-2004$ & $y=63.625 \mathrm{x}-650.985$ (calibrated) & $(9)$ \\
\hline
\end{tabular}

While no calibration data are available, it can be assumed that the trend of decreasing discharges continued after 1983 due to decreasing Lake Albert levels and related vegetation dynamics leading to a decrease of channel capacity. Based on the curves in Fig. 4, regression functions as shown in Table 2 were established. The resulting outflow data was compared with Panyango flow data for validation and shows good correlation as shown in Fig. 5 and Table 3.

\subsection{Torrent runoff and Mongalla flows}

Comparing the CHARM derived torrent flows with the flows derived from historical sources, good qualitative results were found during normal flow conditions while peak events were not captured sufficiently. The same result was found when comparing the calculated flows at Mongalla with measured values as shown in Fig. 6. While qualitatively the time series are comparable, peaks during extreme events are not represented well by the modeling approach. A statistical analysis of the results is shown in Table 4. 
Table 3. Statistical characteristics of Lake Albert outflow $\left(10^{6}\right.$ $\mathrm{m}^{3} /$ month) (mean, minimum, maximum, standard deviation, and correlation coefficient between measured and calculated values). The outflow was calculated from lake level readings with regression functions of Table 2 for the calibration periods $\mathrm{f}$ and $\mathrm{h}$ with available measured flow data at Panyango.

\begin{tabular}{cccccc}
\hline Period & Mean & Min & Max & Std & $R$ \\
\hline $1969-1979$ & 3707 & 2106 & 4813 & 551 & 0.97 \\
$1996-2004$ & 3418 & 1238 & 5062 & 896 & 0.96 \\
\hline
\end{tabular}

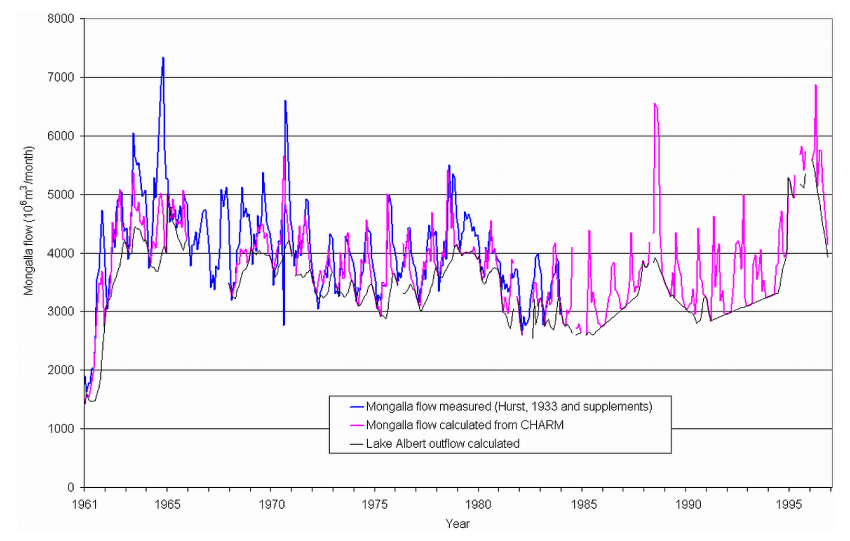

Fig. 6. Comparison of calculated and measured Mongalla flows 1961 to 1983 as well as estimated Mongalla flows 1984 to 1996 , gaps are caused by missing data, the baseflow from 1984 to 1996 is interpolated due to few available measurements.

\section{Discussion}

Evaluating the quality of results obtained in the assessment of Mongalla flows from CHARM data compared to measured data as shown in Fig. 6, the results prove to be of reasonable quality, showing a correlation coefficient of $R=0.81$, the mean deviation was calculated with $4.4 \%$. For the estimated Mongalla flow time series from 1984 to 1996 it has to be taken into account that part of the Lake Albert flow data are interpolated and that, while Lake Victoria outflows which have been compared for this time period confirm the trends, fluctuations in Lake Albert flow are neglected. The obtained Mongalla flows for the 1984 to 1996 period are judged as a reasonable representation of real conditions considering the above statistics and the comparable low fluctuations of Lake Albert outflow.

Considering the spatial approach to estimate runoff quantities from rainfall in the area it has to be taken into account that rainfall events in reality are highly localized while averaged in this study. The derived runoff function can therefore be assumed to underestimate runoff if applied to smaller sections of the catchment area. For the assessed large area anyhow, representative results have been achieved.
Table 4. Statistical characteristics of Mongalla flows $\left(10^{6} \mathrm{~m}^{3} /\right.$ month) (mean, minimum, maximum, standard deviation, and correlation coefficient between measured and calculated values).

\begin{tabular}{cccccc}
\hline Period & Mean & Min & Max & Std & $R$ \\
\hline $1961-1983$ & 3973 & 1426 & 7340 & 742 & 0.81 \\
\hline
\end{tabular}

\section{Conclusions}

Flow records derived from spatial rainfall datasets and lake level time series have been successfully estimated for an ungauged section of the Bahr el Jebel catchment. The results provide a near reality flow time series extending the available Mongalla data for the period from 1984 to 1996. This time series could be further extended using additional available spatial rainfall data. The derived Mongalla flow data will be important for future modeling tasks in the Sudd region for which Mongalla is the key inflow gauging station.

Edited by: F. Portmann, K. Berkhoff, and M. Hunger Reviewed by: two anonymous referees and the editors

\section{References}

Funk, C., Michaelsen, J., Verdin, J., Artan, G., Husak, G., Senay, G., Gadain, H., and Magadazire, T.: The Collaborative Historical African Rainfall Model: Description and Evaluation, Int. J. Climatol., 23, 47-66, 2003.

Entenman, D.: Geospatial Stream Flow Model (GeoSFM) Users Manual, V1.0, FEWSNET Intern, USGS Center for EROS, Sioux Falls, SD, USA, 2006.

ESRI: ArcGIS: The Complete Enterprise GIS, http://www.esri.com/ software/arcgis/, last access 24 December 2007, 2007.

Hurst, H. E. and Phillips, P.: The Nile Basin, Volume V, The Hydrology of the Lake Plateau and the Bahr el Jebel, Schindlers Press, Cairo, Egypt, 1938.

Hurst, H. E. and Phillips, P.: The Nile Basin, Volume IV and Supplements 1-13, Ten Day Mean and Monthly Mean Discharges of the Nile and its Tributaries, Cairo, Egypt, 1933.

JIT - Jonglei Investigation Team: The Equatorial Nile Project and its Effects on the Anglo-Egyptian Sudan, Sudan Government, Khartoum, Sudan, 1954.

Petersen, G., Abeya, J. A., and Fohrer, N.: Spatio-temporal water body and vegetation changes in the Nile swamps of southern Sudan, ADGEO, 11, 113-116, 2007. 